\title{
THE CONCEPT OF EMPLOYER AND THE EXTENSION OF THE SUBJECTIVE (RATIONE PERSONAE) SCOPE OF COLLECTIVE LABOUR LAW
}

\begin{abstract}
In accordance with the changes in the provisions of the collective labour law in force since January 1, 2019, an employer within their meaning is also an organizational unit without civil law subjectivity, if it employs work contractors engaged in paid work engaged in paid work other than employees. This leads to the dualism of the notion and legal construction of the entity employing non-employee contractors on the basis of individual and collective relations. In individual legal relations, the entity employing contractors on the basis of civil law contracts may only be a civil law entity. On the other hand, in collective labour relations, organizational unit without civil law capacity may be regarded as their employer. The purpose of this study is to give the reasons for the thesis that such regulation leads to legal confusion, and the most appropriate way to remove it is to link the employer's subjectivity with civil law subjectivity in individual and collective labour law.

Keywords: employer, employee, work contractor, civil law capacity, paid work performing relations, collective labour relations.
\end{abstract}

\section{POJECIE PRACODAWCY A ROZSZERZENIE ZAKRESU PODMIOTOWEGO ZBIOROWEGO PRAWA PRACY}

Streszczenie. Zgodnie ze zmianami przepisów zbiorowego prawa pracy obowiązującymi od 1 stycznia 2019 r., za pracodawcę w ich rozumieniu uznaje się także jednostkę organizacyjną niemającą podmiotowości cywilnoprawnej, jeżeli zatrudnia innych niż pracownicy wykonawców pracy zarobkowej. Prowadzi to do dualizmu pojęcia i prawnej konstrukcji podmiotu, który zatrudnia wykonawców pracy niebędących pracownikami, na gruncie indywidualnych stosunków świadczenia pracy i zbiorowych stosunków pracy. W stosunkach indywidualnoprawnych podmiotem zatrudniającym wykonawców cywilnoprawnych może być bowiem wyłącznie podmiot prawa cywilnego. Natomiast w zbiorowych stosunkach pracy za ich pracodawcę będzie można uznać także jednostki organizacyjne niemające zdolności cywilnoprawnej. Celem niniejszego opracowania jest wykazanie, że taka regulacja prowadzi do zamętu prawnego, a najwłaściwszą drogą do jego usunięcia jest powiązanie podmiotowości pracodawcy z podmiotowością cywilnoprawną $\mathrm{w}$ indywidualnym i zbiorowym prawie pracy.

Slowa kluczowe: pracodawca, pracownik, wykonawca pracy, zdolność cywilnoprawna, indywidualne stosunki świadczenia pracy zarobkowej, zbiorowe stosunki pracy.

* University of Lodz, Faculty of Law and Administration, Department of European, International and Collective Labour Law; zhajn@wpia.uni.lodz.pl 


\section{INTRODUCTORY REMARKS}

The Act of 5 July 2018 amending the Act on Trade Unions and Some Other Acts (Journal of Laws 2018, item 1601; hereinafter referred to as the "Amending Act 2018") significantly expanded the subjective scope of collective labour law. In particular, from the date of its entry into force, the right to associate in trade unions is vested in persons performing paid work, i.e. employees and other persons who provide work for remuneration on a basis other than an employment relationship, if they meet the requirements set out in art. $1^{1}$ point 2 of the Trade Unions Act 1991 (Act of 23 May 1991; consolidated text: Journal of Laws 2019, item. 263). To these persons, hereinafter referred to as "work contractors", the provisions of Chapter Eleven of the Labour Code regarding collective labour agreements as well as the provisions of the Collective Disputes Settlement Act 1991 (Act of 23 May 1991; consolidated text: Journal of Laws 2019, item. 123) apply accordingly. Due to the indicated extension of the subjective scope of collective labour law, the legislator decided that a new regulation of the group of entities using the work of contractors is also necessary. Hence, the concept of creating an autonomous notion of employer for this field of labour law was adopted.

The purpose of this study is to consider whether this change in the shape adopted by the Amending Act has been the right solution.

\section{EVOLUTION OF THE CONCEPT OF EMPLOYER IN COLLECTIVE LABOUR LAW}

\subsection{The period before the Second World War}

At the beginning, it should be noted that for a long-time entities employing work contractors on grounds other than the employment relationship were to a greater or lesser extent covered by the provisions governing collective labour relations. In the interwar period, and in some countries even before World War I, the work of cottage workers was covered by legal protection. This protection was not limited to individual relations and labour administration, but also concerned collective relations. Associations of cottage workers were granted the ability to conclude collective labour agreements. Also in Poland in regained areas previously annexed by Prussia and covered by German collective bargaining law before the introduction of new Polish provisions, the ability to conclude collective agreements was granted to such associations. Associations of agricultural workers and employers whose legal relations related to the performing of work were not based on an employment contract, but on contracts governed by civil law or relations of service regulated in the regulations for servants, also had a specific capacity to conclude collective agreements (the right to collective bargaining, see: Raczyński 1930, 40, 247 et seq., 255-256). Assigning entrepreneurs employing 
cottage workers or agricultural workers the ability to take legal action in the field of collective employment relations, as well as employers employing employees, did not pose legal problems at that time, because they were simply entrepreneurs employing contractors on various legal titles based on uniform legal capacity resulting from being a legal person or a natural person.

\subsection{The years $1945-1991$}

In the period after World War II, until the political transformation of 1989, due to the lack of trade union freedom, there was in fact no collective labour law in the strict sense. Nevertheless, collective labour relations were regulated by law, "socialist trade unions" operated, agreements called collective labour agreements and having some of the key features of those acts were concluded. However, employing contractors other than employees was not a problem at the time in collective labour relationships. Admittedly, since 1985, cottage workers and agents, if they were not employers, had the right to belong to trade unions operating in workplaces but collective labour agreements, in accordance with the pre-war Act on Collective Agreements of 1937 and later with the Labour Code, included only employees. Collective agreements were sectoral. It was only at the end of this period that the so-called company collective agreements and payroll arrangements were allowed.

During this period, a specific legal construction of the employer was also formed, the essence of which was the recognition that organizational units without civil-law subjectivity were also able to employ employees. According to this construction employers can also be internal organizational units of a legal person, if they have been separated organizationally and financially, and the provisions governing the system of that person authorize such unit to employ employees. This legal construction defined in the legal writing as the managerial concept of the employer, as opposed to the so called "ownership concept" (Hajn 2018, 175-180), was finally adopted in 1974 in the Article 3 of the Labour Code and confirmed by subsequent regulations and their judicial interpretation.

It is worth pointing out however, that the aforementioned company agreements and payroll arrangements could only be concluded by entities with legal personality (Art. $241 \S 1$ of the Labour Code in the wording established by the Act of November 24, 1986 amending the Act - Labour Code, Journal of Laws No. 42, item 201). This proves that the legislator at that time was aware of the impossibility to enter into and perform property obligations arising from collective agreements without having civil-law subjectivity.

\subsection{The years 1991-2018}

A new situation arose in 1991 in connection with the entry into force of the laws constituting the collective labour law after the political transformation of 1989. According to the original text of the Trade Union Act 1991, the right of 
association in these organizations was granted not only to employees, but also for members of agricultural production cooperatives, cottage workers and agents if they were not employers. The provisions of this Act were applicable to these groups of work contractors. Importantly, in accordance with the provisions of the Labour Code as amended in 1994, collective agreements could also cover persons providing work on a basis other than an employment relationship (Article 239 § 2). However, because of that the principle of the most favourable provision and the principle of employee's privilege were not extended to these persons, this did not mean that they were guaranteed the minimal nature of the negotiated services. ${ }^{1}$

The Trade Union Act did not contain a separate definition of the employer at that time, therefore the entity defined in Article 3 of the Labour Code should be considered as the employer. This was also confirmed by the Employers' Organizations Act 1991 (The Act of May 23, 1991, Journal of Laws 2015, item 2029) and the Collective Disputes Settlement Act 1991 which after a certain period of recognition that employers in their understanding were only employers conducting business activity, finally assumed that employers in their understanding are entities defined in Article 3 of the Labour Code. At the same time, the Trade Unions Act ordered to apply its provisions to persons other than employees entitled to associate in trade unions (Article 2 parts 6 and 7). The Collective Disputes Settlement Act (Article 6) regulated the scope of its application to members of agricultural production cooperatives, agents and cottage workers in an analogous manner. This justified the interpretation according to which entities employing mentioned above non-employee contractors should be treated as employers in the sphere of their rights and obligations to the extent that the provisions of the Trade Unions Act Trade Unions Act and the Collective Disputes Settlement Act were applicable to this group of work contractors. However, this could only apply to employers with legal capacity within the meaning of Articles 30 and $33^{1}$ of the Civil Code, without which they could not establish employment relationships based on civil law contracts. In this sense the concept of employer in collective law was broader than in individual law, since it also included entities employing non-employee work contractors in the scope of collective labour relations (see: Hajn 2013, 106).

${ }^{1}$ The exception was the remuneration of cottage eworkers, who since 1996 have been guaranteed the right to components of remuneration and benefits related to work, such as for employees, if this right and the scope of its application to contractors were specified in the collective labour agreement, see $\S 12$ of the Regulation of the Council of Ministers of 31 December 1975 on the employee rights of persons engaged in cottage work, Journal of Laws 1976.3.19 as amended. in the wording determined by $\S 1$ point 15 of the Regulation of 28 May 1996 (Journal of Laws 1996 No. 60, item 280) amending the above-mentioned Regulation of June 2, 1996. 


\subsection{The concept of employer in the first version of the draft act of the Amending Act 2018}

Interesting definitions of the employer and work contractors have been presented in the first version of the draft act of the Amending Act 2018 in the Sejm Print No. 1933. According to it, the employer should be understood as an employer within the meaning of art. 3 of the Labour Code, as well as a natural person, legal person or an organizational unit that is not a legal person, to whom the Act confers legal capacity and to whom the provisions on legal persons apply, if they employ a person other than an employee who performs paid work (more: Tomanek 2019, 20). The definition of employer therefore considered the civil law nature of some of the paid work performing relations which collective protection was broadly introduced by the project as well as the consequences of such relationships for the legal construction of the parties. As it was emphasized in the explanatory statement to the bill, the proposed change of the definition of the employer meant that the employer was a party to the contract concluded with the person performing paid work, i.e. both employment contracts and civil law contracts. Unfortunately, at the same time, the weakness of the project was the adoption of various subjective constructions of the employer in labour and civil law relations. As a result, for part of the staff employed under civil law contracts the employer meeting the definition in art. 3 of the Labour Code, but not having civil-legal capacity, would not be an employing entity (see however, the opinion of Baran 2018, $8^{2}$ ). To exercise specific rights and obligations towards such contractors the body of such a unit would have to be authorized to do so by appropriate civil law actions. It would also cause significant difficulties in collective labour relations because employees and contractors employed under civil law contracts would not constitute the same staff. For example, for the purposes of the numerical requirements related to the establishment of a trade union organization, results of a strike referendum, and determination of the representativeness of a trade union organization, this could be a different unit for employees than for other persons engaged in paid work. A collective agreement would have a different scope for both. The only solution in such a situation could be the application of Article $241^{28}$ of the Labour Code allowing for the conclusion of one agreement for employers being part of one legal entity.

The original draft described above was finally changed by the Senate because of amendments contained in its resolution of June 29, 2018 (print number 2682) and subsequently adopted by the Sejm (lower house of parliament). As a result, it adopted the current concept of employer in Article $1^{1}$ point 2 of the Trade Union

${ }^{2}$ According to this opinion, as an employer of non-employee contractors the project also considered an internal organizational unit with no civil law capacity, if it had appropriate organizational and financial separation. 
Act, as amended by the Amending Act 2018. In the course of the preparatory work for this project, the original definition of the person performing paid work was also changed. In particular, the condition of not taking economic risk associated with such work was eliminated from the list of such person's characteristics.

\section{THE CONCEPT OF AN EMPLOYER IN THE CURRENT PROVISIONS OF COLLECTIVE LABOUR LAW}

According to Article $1^{1}$ of the Trade Union Act in the wording specified in the Amending Act 2018, the employer should be understood as an employer within the meaning of Article 3 of the Labour Code and the organisational unit even if it does not have legal personality, as well as a natural person, if they employ a person other than an employee who performs paid work, regardless of the legal basis of this employment. An employer in the light of this provision is therefore an organizational unit, even if it has no legal personality or a natural person, if it employs: (-) employees, or (-) other than employees persons performing paid work or (-) employees and persons other than employees performing paid work. This concept of the employer has also been adopted in the provisions on collective agreements (Article 21 part 3 of the Trade Union Act), in the Collective Disputes Settlement Act 1991 (Article 5) and the Employers' Organizations Act 1991 (Article 1 part 2).

The above definition leaves no doubt as to the intention of the legislator. It clearly indicates that the employer within the meaning of provisions of the collective labour law after the amendments introduced by the Amending Act 2018 is the employer defined in Article 3 of the Labour Code, and moreover, a natural person or organizational unit, with or without legal personality, employing a person other than an employee performing paid work. Therefore, the legislator clearly expressed its intention to recognize as an employer also an entity employing contractors on the basis of civil law contracts, despite the lack of the civil law capacity. Such a conclusion is additionally confirmed in the motives to the Senate resolution of June 29, 2018 above described, where it was clearly stressed that the new definition of the employer in the Trade Unions Act should be consistent with the definition of the employer contained in Article 3 of the Labour Code. From all this it follows that in the legislator's intention for the use of collective labour law an organizational unit without civil law capacity should be treated as if it were a party to civil law contracts like contracts of mandate, agency, cottage work and others, despite the fact that in the individual legal sphere it has no legal capacity to enter them.

This kind of regulation leads to legal confusion, which it seems the legislator when drafting the definition of the employer in the Amendment Act 2018 did not notice. It should be noted that regulating in other acts the individual protection 
of contractors who are not employees, the legislator uses terms consistent with the Civil Code, without questioning the need for entities employing such persons to have civil law capacity. An example would be the provisions of the Act on trade restrictions on Sunday and public holidays (Act of 10 January 2018, Journal of Laws 2018 item 305) or the Act on the minimum remuneration for work (Act of 10 October 2002 on the minimum remuneration for work, Journal of Laws 2018 item 2177) which specify entities employing such persons using terms such as an entrepreneur, a non-entrepreneur organizational unit, without indicating that they do not need to have legal personality. Also, the Labour Code itself, the entity using the work performed by natural persons on a basis other than the employment relationship calls in the Article $304 \S 3$ an entrepreneur who is not an employer (see also Tomanek 2019, 23). As a result, all this leads to the dualism of the notion and legal construction of the entity employing non-employee contractors on the basis of individual and collective relations. In individual legal relations, the entity employing work contractors on the basis of civil law contracts may only be a civil law entity (see Hajn 2018, passim; Tomanek 2019, 25). On the other hand, in collective labour relations, organizational units without civil law capacity ought to be regarded as their employer. Thus, in individual legal relations, the employer for a part of the staff composed of employees may be an employer who has no civil legal capacity within the meaning of Art. 3 of the Labour Code, but for a part of this staff consisting of civil law contractors, a legal person in whose structure the employer operates. In turn in collective relations, a subject who has no civil-law subjectivity will be considered an employer for the entire staff. But then it is not known on what basis the collective actions of such an employer, such as the conclusion of a company collective labour agreement, are to have effects in terms of the individual rights of contractors employed by another legal entity (see also Tomanek 2019, 24-25). It seems that this situation cannot be defended from the point of view of the basic constructions of civil and labour law, correct legislation, logic as well as the needs of proper conduct of legal transactions and proper protection of the work contractor.

\section{DE LEGE FERENDA CONCLUSIONS}

The basic problem that emerges from the above comments is finding a way out of the legal confusion described in the previous section of this study. I believe that two goals should be assumed when looking for such a way out. Firstly, since the legislator wants to use the term employer in the provisions of collective labour law to describe entities employing contractors on various legal grounds, the legal construction of this concept should ensure that the entity has the ability to establish both employment relationships and civil law work-based relationships. Secondly, this entity should be able to take legal actions in the field of collective 
labour relations for the entire staff, i.e. its members who are employees as well as members performing work on the basis of civil law contracts and administrative acts.

These goals can only be achieved by changing the law by accepting that the employer within the meaning of the Article 3 of the Labour Code and within the meaning of the provisions of the collective labour law is an entity having the capacity under civil law within the meaning the Article 33 and art. $33^{1}$ of the Civil Code. According to this assumption, the Article 3 of the Labour Code should state that: The employer is a natural person, a legal person or an organizational unit which is not a legal person, to whom the law confers legal capacity and to which the provisions on legal persons apply, being a party to the employment relationship. In turn, the definition in collective labour law could be as follows: An employer within the meaning of this Act is a natural person, a legal person or an organizational unit that is not a legal person, to whom the law confers legal capacity and to which the provisions on legal persons apply, employing persons engaged in paid work. If this proposal is adopted, the definition of an employer in collective labour law will include both the employer in the strict sense - the party to an employment relationship as well as the orderers in contracts of mandate and in agency contracts, entrepreneurs in cottage industry and other entities entering into civil-law dependent work-based relations or administrative-law employment relations.

Arguments for adopting such an "ownership concept" in individual and collective labour law have already been repeatedly presented in the doctrine, hence there is no need for extensive repetition. Summing up this argumentation, it should be stated only that the proposed concept:

- consolidates the entity employing employees and other work contractors in individual work-based relations, basing it on the same concept of legal capacity and allowing the same natural person or organizational unit to be simultaneously a party to various dependent work-based relationships;

- consolidates the employer's subjectivity in individual and collective labour law;

- consolidates the subjectivity of the employer with his/her/its subjectivity as an entrepreneur and more generally with his/her/its subjectivity in civil law relations;

- makes the legal construction of the employer real, combining it with an entity disposing property and capable of making property disposals and accepting property increments, which is necessary for the realization of rights and obligations arising from the employment relationship and other relations connected therewith, other relationships of dependent work and relations connected thereto as well as collective labour relations;

- harmonizes the Polish concept of employer with its standard understanding in other countries and in EU law. 


\section{BIBLIOGRAPHY}

Baran, Krzysztof W. 2018. "O pojęciu pracodawcy w zbiorowym prawie pracy - uwagi de lege lata i de lege ferenda". Monitor Prawa Pracy 3: 7-10.

Hajn, Zbigniew. 2013. Zbiorowe prawo pracy. Zarys systemu. Warszawa: Wolters Kluwer Polska S.A.

Hajn, Zbigniew. 2017. "Podmioty stosunku pracy. Pracodawca". In System prawa pracy. Tom II. Indywidualne prawo pracy. Edited by Grzegorz Goździewicz. 144-191. Warszawa: Wolters Kluwer.

Raczyński, Aleksander. 1930. Polskie prawo pracy. Warszawa: Księgarnia F. Hoesicka.

Tomanek, Artur. 2019. "Wątpliwości wokół nowej definicji pracodawcy w prawie związkowym". Praca i Zabezpieczenie Społeczne 3: 19-27. 